\title{
Fairy Tale Futures: Critical Reflections
}

\author{
Praet, S., \& Kérchy, A. (Eds.). (2019). The fairy tale vanguard: \\ Literary self-consciousness in a marvelous genre. Newcastle \\ upon Tyne: Cambridge Scholars.
}

\section{Abstract:}

This article provides critical reflections on Stijn Praet and Anna Kérchy's edited collection, The Fairy Tale Vanguard: Literary Self-Consciousness in a Marvelous Genre (2019). Vanguard can be defined as "the foremost part of an advancing army or naval force," with established and emerging critics marching in defence of the fairy tale against the genre's complicated reception throughout the ages. The form's self-consciousness and intertextual complexity is foregrounded, with fairy tale experiments ranging from those of $17^{\text {th }}$-century French female conteuses, to modernist short stories and contemporary films, which all combine into a celebration of the genre's sophistication and continued relevance. The book engages with the generic complexity of the fairy tale, defying any kind of neat categorisation. 'Fairy tale' often functions as a 'catch-all' term for different fairy tale narratives, but this study paves the way for reflections on new subgenres such as the 'anti-tale'. Finally, it is suggested that Rikki Ducornet's idea of the 'deep magic' of fairy tales opens us up to a possibility, to an embrace of the unknown and all of its potentiality, providing us with an imaginative space within which to envision a new and better reality. This is foregrounded as a central tenant to The Fairy Tale Vanguard's privileging of experimentation, which highlights that the fairy tale harnesses a deeply political potential in challenging current oppressions. Perhaps it is not us, fairy tale scholars, who are marching to the aid of the fairy tale then, rather it is the tales fighting for us in an unjust world.

Key words:

Anna Kérchy, anti-tale, fairy tale, genre theory, imagination, literature, Stijn Praet

* Kendra Reynolds - PhD, was the 2019-20 Fulbright Scholar-in-Residence at the University of Tulsa and Tulsa Community College (United States). Her research interests include $21^{\text {st }}$-century anti-tales, feminist literature and theory, and the concepts of space, time, and bodies in literature. Contact: ker8998@utulsa.edu. 


\section{Baśniowe przyszłości. Krytyczne refleksje}

Praet, S., Kérchy, A. (red.). (2019). The fairy tale vanguard: Literary selfconsciousness in a marvelous genre. Newcastle upon Tyne: Cambridge Scholars.

\section{Abstrakt:}

Artykuł zawiera krytyczne refleksje na temat zredagowanego przez Stijna Praeta i Annę Kérchy zbioru The Fairy Tale Vanguard: Literary Self-Consciousness in a Marvelous Genre [Baśniowa awangarda. Literacka samoświadomość cudownego gatunku] (2019). Awangardę można zdefiniować jako „wysunięty oddział posuwających się naprzód sił zbrojnych lub morskich”, uznani i młodzi krytycy maszerują zaś w obronie baśni - gatunku mającego skomplikowaną recepcję na przestrzeni wieków. Na pierwszy plan wysuwa się samoświadomość formy i jej intertekstualna złożoność, baśniowe eksperymenty sięgają bowiem od XVII-wiecznych francuskich conteuses po modernistyczne opowiadania i współczesny film, a wszystko to łączy się w celebrację wyrafinowania gatunku i jego nieustającej aktualności. Książka porusza temat gatunkowej złożoności baśni, które nie poddają się jakiejkolwiek prostej kategoryzacji. Termin „baśń” często funkcjonuje jako „słowo-wytrych” dla różnych narracji baśniowych, co toruje drogę do refleksji nad nowymi podgatunkami, takimi jak „antybaśń”. Wreszcie, zasugerowano, że idea „głębokiej magii” baśni, zaproponowana przez Rikki Ducornet, otwiera przed nami możliwości i pozwala na akceptację tego, co nieznane, oraz potencjału, który owo nieznane ze sobą niesie. W ten sposób zyskujemy imaginacyjną przestrzeń, umożliwiającą snucie wizji o nowej i lepszej rzeczywistości. Jest to centralna perspektywa zaproponowanego w The Fairy Tale Vanguard uprzywilejowania eksperymentów, w ten sposób podkreślone zostaje bowiem przekonanie, że baśń wykorzystuje swój głęboki polityczny potencjał w walce ze współczesnymi przejawami opresji. Być może więc nie my, badacze baśni, maszerujemy, by jej pomóc, lecz w niesprawiedliwym świecie to baśnie walczą w naszym imieniu.

\section{Słowa kluczowe:}

Anna Kérchy, antybaśń, baśń, teoria gatunków, wyobraźnia, literatura, Stijn Praet

CT anguard' comprises two meanings: the first being "the foremost part of an advancing army or naval force," and the second, "a group of people leading the way in new developments or ideas" ("Vanguard," n.d.). Indeed, The Fairy-Tale Vanguard: Literary Self-Consciousness in a Marvelous Genre combines both elements in a critical text that marches for the ongoing need for study of the fairy tale in academia, led by editors Stijn Praet and Anna Kérchy (2019). The book constitutes a series of essays by both experienced and emerging critics at the forefront of current fairy tale scholarship, exploring themes 
related to the book's two halves entitled "Metaliterary Experimentations" and "Intergeneric, Stylistic and Linguistic Experimentations." It is clear to the reader of this text that it is the product of a conference, one that was held at the University of Ghent in Belgium in 2012, and the result is a mixed array of various aspects of contemporary fairy tale criticism; the essays being extremely diverse. This does make the collection feel like a bit of a mixed bag and so, for anyone seeking a more cohered overview of contemporary fairy tale criticism, Teaching Fairy Tales, edited by Nancy L. Canepa (2019), is perhaps the place to start. However, having said this, Canepa's collection is also an amalgamation of established ideas from renowned scholars in the field: including Jack Zipes, Maria Tatar, and Donald Haase. In contrast, The Fairy Tale Vanguard builds from this base and provides an innovative source for further study into specific aspects of contemporary fairy tale experimentations, as well as introduces us to much-needed fresh new voices.

Ever since reading Kérchy's (2011) Postmodern Reinterpretations of Fairy Tales: How Applying New Methods Generates New Meanings, I knew that her rich theoretical or philosophical approach and willingness to push boundaries, to enter into the sometimes overwhelming complexity of postmodern fairy tale criticism, would be evident in this collection too: an approach which, though sometimes dense, often produces the most rewarding and thorough results. This provides a stark contrast to the socio-historical cataloguing or overview of tale types and contexts that dominated fairy tale scholarship up until the end of the $20^{\text {th }}$ century. Whilst I acknowledge the value and importance of such a work, it threatened to make the field stale and stagnant, often not leaving enough room for close-readings of texts and side-lining the ideological and theoretical nuances of the genre. Thankfully, things started to shift with the publication of Postmodern Fairy Tales: Gender and Narrative Strategies by Cristina Bacchilega (1997), Twice Upon a Time: Women Writers and the History of the Fairy Tale by Elizabeth Wanning Harries (2001), and a collection Fairy Tales and Feminism: New Approaches, edited by Donald Haase (2004). Following such publications, postmodern fairy tale criticism has taken an increasingly theoretical turn in the $21^{\text {st }}$ century.

Whilst The Fairy Tale Vanguard does contain essays that chart tale development, it does so in ways that shine new light upon, and complicate, established histories. For example, Sophie Raynard's (2019) essay, “The Modernist Political Agenda of the First Contes de Fées: Mademoiselle Lhéritier, Madame D'Aulnoy, and Madame de Murat's Paratexts," does not simply repeat the idea of these women using the fantasy of the fairy tale as a veil for their political discontent behind the closed doors of their salons. Rather, Raynard foregrounds 
how these women actively became entrepreneurs, "market[ing] the fairy tale as modern and worthy literature" (p. 18); positioning themselves within the contemporary debate regarding 'the Ancients' and 'the Moderns'; and advocating for a new genre that would assist in progress, breaking with the nostalgia for an idealised past, and looking to the future. In addition, study of Perrault has been extensive and yet Ute Heidmann's (2019) chapter, "Perrault's Vanguard Experimentation with Apuleis, Basile and History: Sleeping Beauty, Psyche and the Bourbon Princess," foregrounds both his complex intertextual ties with understudied authors like Basile and the "metapoetical importance of having chosen the historical Bourbon Princess as the emblematic reader of the volume," which "reveals a potentially subversive political dimension of this bold poetic experimentation" (p. 37). After all, in 1695 the Bourbon princess was still unmarried and "her royal destiny was to serve as human capital in the struggle for political and financial power of the Bourbon dynasty and especially Louis XIV" (pp. 42-43). Therefore, in Perrault's intertextual experimentations and dedicatory letter, it is argued that "the Bourbon Princess receives more instructions on how to gain insight into her personal and political situation by comparing her destiny to those of Psyche and Sleeping Beauty" (p. 43).

Overall, this book seeks to move forward, or to at least shine new light into a well-worn terrain. As Praet (2009) points out in his introduction, the cover image has been extracted from Jonathan Swift's mock-epic satire The Battle of the Books: 'Swift's text recounts how the books at St James' Library have become animated by the spirits of their creators to have it out with one another - classical versus contemporary authors, but also critics versus their literary objects" (p. 1). The Fairy Tale Vanguard embraces this idea of dialogue and conversation by including essays from two leading scholars (Ruth B. Bottigheimer, 2019 - "Response to Part One," and Harries, 2019 - "Response to Part Two: 'Wondering and Wandering' in Fairy Tale Studies") constituting responses to the essays in each section of the book. This is a meta-aware collection then, one that is willing to produce new insights whilst simultaneously opening itself up to scrutiny. For it is true that both critical responses challenge certain elements of essays within the book. One example of this can be found in relation to Richard van Leeuwen's (2019) essay "Fairy Tales and Genre Transformation: The Influence of The Thousand and One Nights on French Literature in the Eighteenth-Century" in which he discusses "three frame narratives that were deeply influenced by Nights," Harries (2019) taking this further by stating: "In all three narratives, however, I would insist on another probable model for their games with translation from the Arabic, editing, and authenticity: Cervantes's Don Quixote. Van Leeuwen's account of the way these narratives 
use the Nights' frame, however, leads to interesting conclusions about cultural hybridity" (p. 248). In this way, the collection invites a critical eye and further extrapolation of ideas shared, knowing that it is an approach that strives for academic rigour, paving the way for new directions and interpretations. Another example can be found in Harries (2019) agreeing with a point I made earlier, stating that:

[...] the six essays at the end of this volume explore very different things: fairytale genres, linguistic innovation in tales old and new, the incorporation of wellknown tales in later fiction, the transmission of tales nationally and internationally. They also focus on different centuries, from the early eighteenth century to the twenty-first. But what do they have in common? (p. 247).

Again, this is no doubt a result of the book's inception at a conference, but Harries also notes, what loosely binds each essay is the fact that "they all, in their different ways, show how deeply fairy tales are woven into the European narrative tradition [...]. Though our ideas about the origins of these tales and the shape they must take are always shifting, they remain a powerful narrative resource" (p. 247). In essence, The Fairy Tale Vanguard points to the future for fairy tale scholars, welcoming criticism and allowing new discourse to emerge from its findings.

Returning to the cover art, the idea of texts speaking is extremely pertinent (and indeed complicated) when it comes to fairy tales, which are of course derived from a complicated intersection of oral folk tales, literary stories, intersections of cultures, and a myriad of influences that inform each new author or collector. Fairy tale history is not linear and extremely complex. Tales are constructed as palimpsests, each retelling a new skin layered on top of older versions, creating (as the book's title asserts) extremely 'self-conscious' and selfanimated texts that speak both for, and beyond, their respective authors and time periods. Like the divergent voices of multiple scholars in this collection, fairy tales are constantly evolving over time to speak a plethora of different truths to each society. Jessica Tiffin's (2019) essay, "Princesses and Lift-Men: The Contemporary as Self-Conscious Play in E. Nesbit's Fairy Tales," is particularly interesting in this respect. Tiffin notes how "for all its timelessness, its abstracted realm dislocated from the geography and chronology of the real, there is nonetheless an intrinsic historicity to the classic fairy tale. Its essentialized structures offer themselves with a deceptive openness to revision, which allows them to be updated to fit almost any context" (p. 77). This idea that the old haunts the new is extremely important because "any update, but particularly 
any politically radical one, must grapple self-consciously with the fairy tale's innate resistance to the progressive" (p. 78). Hence, whilst the fairy vanguardism evident in this collection supports the importance and progressiveness of the fairy tale in many respects, Tiffin's essay is an important reminder that the genre's conservative elements need to be addressed and confronted too.

Sticking to the notion of vanguard, the critics in this new collection come to the defence of the fairy tale in confronting its rather complicated reception as "an underdog genre" (Praet, 2019, p. 7) throughout the ages, trivialised by some as a form of childish, popular, even vulgar, entertainment. The scholars here acknowledge that their defence of the fairy tale is part of a centuries-long tradition, merging their voices with fellow fairy tale advocates who have fought the struggle throughout history, the two sections of the collection spanning from $17^{\text {th }}$ - and $18^{\text {th }}$-century tales to contemporary retellings. These essays highlight how the fairy tale's worth was espoused by many: the female conteuses in $17^{\text {th }}$-century France who "marketed the fairy tale as modern and worthy literature" distinct and purified from the oft denigrated "mother goose tales" (Raynard, 2019, p. 18); Anna Kerchy's (2019) “Meta-Imagination in Lewis Carroll's Literary Tale Fantasies about Alice's Adventures" foregrounding Lewis Carroll's defence of the genre in his "quest for a new fairy tale form [that] stemmed from the psychological rejection and rebellion against the 'norms' of English society" (p. 55) through his sophistication of 'play' and the power of the imagination; Maria Casado's (2019) "Excavating the Very Old to Discover the Very New: The Modernist Fairy Tales of D. H. Lawrence and Katherine Mansfield" highlights how both authors, in their fairy tale experiments within modernist short-stories, prove that, "although classic fairy tales often serve to perpetuate the governing values and mores, they also offer possibilities for the expression of the marginal and the rebellious" (pp. 197-198); even contemporary film director Tommy Wirkola's often denigrated film asserts itself in William De Blécourt's (2019) “The Witch in the Oven: Exploring Hansel \& Gretel: Witch Hunters," not as mere brainless, gory entertainment but urges us to engage with the fairy tale's rich intertextual and historical evolution in the complication of witches to break down the dichotomy of good vs. evil. Whilst these examples constitute only a drop in the ocean of fairy tale vanguardism, they are part of a movement that recognises the integral importance of fairy tales in our social and political lives.

One aspect I find particularly interesting is the collection's willingness to engage with the generic complexity of the fairy tale and its boundaries of demarcation. Bottigheimer's (2019) response essay to part one notes this thread and openly asks: "What is a fairy tale?" (p. 132). Indeed, critics generally agree 
that this is an extremely complex question and there is no neat answer. The fairy tale's constant evolutions and mutations defy any kind of neat categorisation. As Bottigheimer notes, "oddly, a commonly accepted history and definition of fairy tales seems not to exist. That absence allows the diversity of fairy tale meta-genres that patently exist to join the fairy tale genre in The Fairy Tale Vanguard" (p. 133). Van Leeuwen's (2019) essay notes that "these questions are notoriously difficult to answer and we could even ask ourselves whether or not precise definitions of genres are useful at all" (p. 139). Indeed, in his introduction, Praet (2019) states that "For the present volume, we have chosen to adopt an open approach as to what kinds of text we are willing to consider in terms of the fairy tale tradition, including fairy tale parodies and deconstructions (no 'anti-tale' without a tale), realistic short stories, Surrealist vignettes, nonsenseliterature, Oriental tales, action/horror films, etc." (p. 6). Many critics have begun to recognise the limitations of the term 'fairy tale' and a host of fairy scholars have advocated for the term 'wonder tale,' for example, to be more inclusive of traditions outside of Western Europe. In addition, there has been a lot of hostility towards the term 'anti-tale' in fairy tale scholarship to date and this collection is still muted in its discussion of the genre. Yet, it is interesting and somewhat encouraging that, in this collection, there are at least a few examples of authors reflecting that 'fairy tale' does not seem to fully capture the subversions of the texts they study. Bottigheimer (2019) also openly acknowledges that tales studied within this collection are "consistent with the antifairy-tale genre" (p. 134). For example, Björn Sundmark's (2019) essay "Fairying the Avant-Garde in Par Lagerkvist's Evil Fairy Tales" consistently points out the author's use of traditional fairy tale motifs with the primary function of deconstructing them:

For when the genre expectations are met on the formal narratological level and then thwarted on the level of ethos and meaning, this leads not only to close inspection of what Lagerkvist is doing, but the conventions and clichés of traditional fairy tales appear in a new light as well (p. 109).

Sundmark notes many of the anti-tale architectural traits identified in my book, The Feminist Architecture of Postmodern Anti-Tales: Space, Time \& Bodies (Reynolds, 2020): examples include the subversion of traditional fairy tale simplicity with complexity, endings which lack closure and comfort, "no moralizing, no attempt to rationalize" (Sundmark, 2019, p. 107), and hierarchies and binaries of all kinds, are radically compromised. Emeline Morin's (2019) "Cartesian Wit and American Fantasy: A Comparative Study of Eric 
Chevillard's Le Vaillant Petit Tailleur (2003) and Robert Coover's Briar Rose (1996)" notes that, for both authors, "the focus of the rewritings is not so much about a simple shift of plots, as it is about questioning the fairy tale genre as a whole" (p. 113). Indeed, in my book, the anti-tale is defined as having a different architecture from the fairy tale which makes it distinct and identifiable (whilst still of course inevitably being linked to the fairy tale genre from which it is born), and here Morin tellingly points out that it is the structure that distinguishes these contemporary tales and which constitutes their difference and subversions of the traditional fairy tale: "By keeping the original plots in the background, and introducing new, previously unavailable versions the two authors paradoxically question and deconstruct the very structure of the fairy tale" (p. 120). Overall, she concludes that they establish "a new form within which to tell their tale" (p. 126). Whilst Morin does not assert anti-tale as that "new form" here, there are a lot of affinities to definitions and characteristics of anti-tale architecture identified in my book. Whilst it is not the purpose of this review to advocate for the anti-tale or to define it at length, it is encouraging that the new fairy tale criticism evident in this collection is now tackling genre questions head on and dropping some of the conservatism many fairy tale scholars have displayed in their rejection of new definitions for different kinds of fairy tale literature. Indeed, I absolutely agree that there are no neat answers or solutions but applaud the collection's apparent willingness to acknowledge that 'fairy tale' often constitutes a limited umbrella term for the genre's various manifestations. Again, it is the willingness of the collection to not shy completely away from tough questions that is central to its integrity in contributing to moving the fairy tale scholarship into a new age. It is this willingness to open our minds to new directions in scholarship that is essential in doing justice to what Praet (2019) calls "a very protean genre that has always continued to refashion itself in relation to other genres and artistic developments and movements, also in different ways at the same time" (p. 6).

On that note, in answer to Harries's (2019) questions - "Where are fairytale studies going? Where should they be going? Who and what are we neglecting? How can we contribute to new directions?" (pp. 251-252) - questions of genre and generic experimentation are definitely ripe for exploration and will require much thought and unravelling. I also agree with Harries that, despite the range of tales with varying geographical locations discussed here - including England, France, Italy, Denmark (in Helen Høyrup's, 2019, “Little Worlds of Words and Things: The Intergeneric and Linguistic Innovation of Hans Christian Andersen's Fairy Tales") and Romania (in Daniel Gicu's, 2019, "The Role of Fairy Tales in the Formation of Romanian National Literature") - we need 
to start looking even further beyond European fairy tales and making fairy tale scholarship more global and inclusive, creating new "collaborative anthologies and/or websites that give access to a far wider and more inclusive set of texts, films, pictures, diagrams, and other materials. We should include things that are interdisciplinary, nomadic, creolized, uncanonical, strange" (Harries, 2019, p. 254). With the openness and favouring of complexity that this collection represents, I believe we are in a good place to move forward in this way within fairy tale studies.

One other inclusion, which brings The Fairy Tale Vanguard to a close, is an interview between Michelle Ryan-Sautour and author Rikki Ducornet (2019), entitled “Interview with a Vanguard Author." Here, Ducornet's personal affinity with the fairy tale genre provides a wonderful break from the deeply theoretical essays preceding the interview, reminding us that fairy tales are not simply objects of scholarly enquiry but have a significant and profound personal impact on individual lives: "When I was twelve or thirteen, a colleague of my father's brought me a large box of books, bound in red leather, their pages uncut: a seemingly exhaustive collection of fairy tales from everywhere [...] My imagination has been chronically infected with fairy tales ever since" (pp. 256-257). What is striking is Ducornet's reflections on the fairy tale's development of her seemingly ecofeminist consciousness and connectedness to other creatures and the natural world beyond society's artificial hierarchies and divisions: "Perhaps the reason why we are returning to fairy tales now is because they flourished in times of ecological diversity and health. I am not convinced we can survive as a species without the mystery of 'deep magic' of wilderness. If there is no living world around us, how do we identify ourselves?” (p. 257). Indeed, society upholds its power structure by trying to rationalise the world into neat categories and definitions, as if everything in nature is understandable and easily quantified. It should be noted that Michelle Ryan-Sautour's (2019) chapter, "The Linguistic Punctum in Rikki Ducornet's The Complete Butcher's Tale (1994) and The One Marvelous Thing (2008)," provides a critical examination of these ideas within two of Ducornet's works and functions as a good base for this interview that follows at the book's close.

To conclude then, vanguard also implies to me a bigger, ongoing battle in the contemporary society: the postmodern fairy tale and its various different manifestations are prodding us awake, preparing us for a battle against an increasingly amoral and disenchanting society that favours hierarchies and divisions. As noted above, there is "an ethical dimension" to the fairy tale's "feeding of the imagination," "it's a question of identity, of personhood, of moral life. Sanity is all about a healthy co-existence with all with which we have evolved. 
Responsible coexistence is deeply moral" (Ducornet \& Ryan-Sautour, 2019, p. 258). After all, folk and fairy tales have always given communities a means of working through their social positioning and dilemmas, have helped the young and the old to both understand their place in the world and maintain hope that change is possible. Zipes (2012) has consistently reminded us that fairy tales are "necessary to shake up the world and sharpen our gaze" (p. 136), and perhaps this is true now more than ever. Ducornet (\& Ryan-Sautour, 2019) powerfully points out in her interview that "we live in a perilous culture that embraces, even glorifies violence, and yet it is ideas - of racial justice for example - that make people "uncomfortable,"' a world where refugees are sent back to the horrors from which they fled, one young boy threatened with deportation describing how, "the entire time he was catatonic [from the trauma,] he had believed he was a prisoner in a glass box at the bottom of the sea, and if he moved the glass would break and he would die" (pp. 262-263). Ducornet is right then in asserting how fairy tale monsters provide perfect metaphors for current political realities, concluding with a powerful Carrollesque warning for us to fight these new demons and restore order, or perhaps a more progressive disorder: "Once you read Carroll's The Hunting of the Snark, you know a Boojum when you see one [...]. Humpty Dumpty is a snark of the provincial type - as is Steve Bannon. Trump started off as a snark, but prodded by a host of snarks, is well on the way to becoming Boojum. Time the Jabberwocky snapped up the entire mob" (p. 266). Clearly, fairy tales and their various subgenres and manifestations harness immense potential in challenging current oppressions and perhaps it is not us, fairy tale scholars, who are marching to the aid of the fairy tale, rather it is the tales fighting for us in an unjust world.

\section{References}

Bacchilega, C. (1997). Postmodern fairy tales: Gender and narrative strategies. Philadelphia, PA: University of Pennsylvania Press.

Bottigheimer, R. B. (2019). Response to Part One. In S. Praet \& A. Kérchy (Eds.), The fairy tale vanguard: Literary self-consciousness in a marvelous genre (pp. 129-135). Newcastle upon Tyne: Cambridge Scholars.

Casado Villanueva, M. (2019). "Excavating the very old to discover the very new": The modernist fairy tales of D. H. Lawrence and Katherine Mansfield. In S. Praet \& A. Kérchy (Eds.), The fairy tale vanguard: Literary self-consciousness in a marvelous genre (pp. 193-212). Newcastle upon Tyne: Cambridge Scholars.

De Blécourt, W. (2019). The witch in the oven: Exploring Hansel \& Gretel: Witch Hunters. In S. Praet \& A. Kérchy (Eds.), The fairy tale vanguard: Literary self-con- 
sciousness in a marvelous genre (pp. 229-249). Newcastle upon Tyne: Cambridge Scholars.

Ducornet, R., \& Ryan-Sautour, M. (2019). Interview with a vanguard author. In S. Praet \& A. Kérchy (Eds.), The fairy tale vanguard: Literary self-consciousness in a marvelous genre (pp. 247-2155). Newcastle upon Tyne: Cambridge Scholars.

Gicu, D. (2019). The role of fairy tales in the formation of Romanian national literature. In S. Praet \& A. Kérchy (Eds.), The fairy tale vanguard: Literary self-consciousness in a marvelous genre (pp. 175-192). Newcastle upon Tyne: Cambridge Scholars.

Haase, D. (2004). Fairy tales and feminism: New approaches. Detroit, MI: Wayne State University Press.

Harries, E. W. (2001). Twice upon a time: Women writers and the history of the fairy tale. Princeton, NJ: Princeton University Press.

Harries, E. W. (2019). Response to Part Two: "Wondering and wandering" in fairy-tale studies. In S. Praet \& A. Kérchy (Eds.), The fairy tale vanguard: Literary self-consciousness in a marvelous genre (pp. 247-255). Newcastle upon Tyne: Cambridge Scholars.

Heidmann, U. (2019). Perrault's vanguard experimentation with Apuleius, Basile and history: Sleeping Beauty, Psyche and the Bourbon Princess. In S. Praet \& A. Kérchy (Eds.), The fairy tale vanguard: Literary self-consciousness in a marvelous genre (pp. 37-54). Newcastle upon Tyne: Cambridge Scholars.

Høyrup, H. (2019). Little worlds of words and things: The intergeneric and linguistic innovation of Hans Christian Andersen's fairy tales. In S. Praet \& A. Kérchy (Eds.), The fairy tale vanguard: Literary self-consciousness in a marvelous genre (pp. 154-174). Newcastle upon Tyne: Cambridge Scholars.

Kérchy, A. (2011). Postmodern reinterpretations of fairy tales: How applying new methods generates new meanings. Lewiston, ME, \& Lampeter: Edwin Mellen Press.

Kérchy, A. (2019). Meta-imagination in Lewis Carroll's literary fairy-tale fantasies about Alice's adventures. In S. Praet \& A. Kérchy (Eds.), The fairy tale vanguard: Literary self-consciousness in a marvelous genre (pp. 55-76). Newcastle upon Tyne: Cambridge Scholars.

Morin, E. (2019). Cartesian wit and American fantasy: A comparative study of Eric Chevillard's Le Vaillant Petit Tailleur (2003) and Robert Coover's Briar Rose (1996). In S. Praet \& A. Kérchy (Eds.), The fairy tale vanguard: Literary self-consciousness in a marvelous genre (pp. 111-128). Newcastle upon Tyne: Cambridge Scholars.

Praet, S. (2019). Introduction. In S. Praet \& A. Kérchy (Eds.), The fairy tale vanguard: Literary self-consciousness in a marvelous genre (pp. 1-17). Newcastle upon Tyne: Cambridge Scholars.

Praet, S., \& Kérchy, A. (Eds.). (2019). The fairy tale vanguard: Literary self-consciousness in a marvelous genre. Newcastle upon Tyne: Cambridge Scholars.

Raynard, S. (2019). The modernist political agenda of the first Contes de Fées: Mademoiselle Lhéritier, Madame D’Aulnoy, and Madame de Murat's paratexts. 
In S. Praet \& A. Kérchy (Eds.), The fairy tale vanguard: Literary self-consciousness in a marvelous genre (pp. 18-36). Newcastle upon Tyne: Cambridge Scholars.

Reynolds, K. (2020). The feminist architecture of postmodern anti-tales: Space, time e bodies. London: Routledge.

Ryan-Sautour, M. (2019). The linguistic punctum in Rikki Ducornet's The Complete Butcher's Tales (1994) and The One Marvelous Thing (2008). In S. Praet \& A. Kérchy (Eds.), The fairy tale vanguard: Literary self-consciousness in a marvelous genre (pp. 213-228). Newcastle upon Tyne: Cambridge Scholars.

Sundmark, Björn (2019). Fairying the avant-garde in Pär Lagerkvist's Evil Fairy Tales. In S. Praet \& A. Kérchy (Eds.), The fairy tale vanguard: Literary self-consciousness in a marvelous genre (pp. 92-110). Newcastle upon Tyne: Cambridge Scholars.

Tiffin, J. (2019). Princesses and lift-men: The contemporary as self-conscious play in Edith Nesbit's fairy tales. In S. Praet \& A. Kérchy (Eds.), The fairy tale vanguard: Literary self-consciousness in a marvelous genre (pp. 77-91). Newcastle upon Tyne: Cambridge Scholars.

Vanguard. (n.d.). In Lexico: Powered by Oxford. Retrieved from https://www.lexico. com/en/definition/vanguard.

Van Leeuwen, R. (2019). Fairy tales and genre transformation: The influence of The Thousand and One Nights on French literature in the eighteenth century. In S. Praet \& A. Kérchy (Eds.), The fairy tale vanguard: Literary self-consciousness in a marvelous genre (pp. 138-153). Newcastle upon Tyne: Cambridge Scholars.

Zipes, J. (2012). The irresistible fairy tale: The cultural and social history of a genre. Princeton, NJ: Princeton University Press. 